\title{
Hepatocellular Carcinoma and Sorafenib: How can we improve on the Current Standard of Care in Advanced Disease?
}

\author{
Olowokure Olugbenga*, Singeltary Brian, Ghose Abhimanyu, Kundu Ria, Tefera Kirubel \\ Department of internal medicine, University of Cincinnati, USA
}

Submission: March 05, 2017; Published: March 16, 2017

"Corresponding author: Olugbenga O. Olowokure MD, Associate Professor of Medicine, Department of internal Medicine, Division of Hematology Oncology, University of Cincinnati Ohio, Vontz Center for Molecular Studies ML0562, 3125 Eden Avenue Cincinnati Ohio 45267, Tel: 513-558-2113; Fax: 513-558-2124; Email: olugbenga.olowokure@uc.edu

\section{Introduction}

Sorafenib at a starting daily dose of $400 \mathrm{mg}$ twice daily $(800 \mathrm{mg} / \mathrm{d})$ is considered the standard systemic therapy for advanced unresectable hepatocellular carcinoma (HCC), in patients with well-preserved liver function. It remains the only FDA-approved chemotherapeutic agent with a category 1 NCCN recommendation for patients with advanced liver cancer. Due to complaints regarding side effects voiced by patients themselves and the reluctance to continue at full dose by many practicing physicians. We retrospectively reviewed patients in our liver cancer database that started sorafenib at a total daily dose of $400 \mathrm{mg}$ (200 mg twice daily). This single institution retrospective review, evaluated the experience of the impact of starting sorafenib at a total daily dose of $400 \mathrm{mg}$ daily.

\section{Results}

A total of 33 patients (M: F, 21: 12) with mean age of 59.8y (SD: 12.40 ) were included in the analysis/ met inclusion criteria, the median duration of follow up after starting treatment was 8.7 months. AFP was elevated (>8.3ng/ml) in $23(70 \%)$. Of those with abnormal AFP, AFP decrease $>50 \%$ from baseline in 8 (35\%). Initial dose tolerability (defined as ability of patient to stay on prescribed dose of $400 \mathrm{mg} /$ day for at least 1 month without the need for dosereduction) was observed in $70 \%$ of patients. $49 \%$ needed dose reduction while $58 \%$ were able to dose escalate at some point in therapy. Median duration on $200 \mathrm{mg}$ twice daily dose $(400 \mathrm{mg} / \mathrm{d})$ was 3 months prior to any adjustment (CP-A: 3 months, CP-B: 2 months). Mean duration of sorafenib use was $8.88 \mathrm{~m}$ (CP-A-10.04 months, CP-B-6.2 months), 26 (79\%) patients had progression and $24(73 \%)$ patients died during follow up. There was no difference in progression-free survival between CP-A and B. Following first progression of disease 53\% (10/19) evaluable patients continued sorafenib. OS was $79 \%$ at 3 months, $67 \%$ at 6 months, $50 \%$ at 9 months, and $40 \%$ at 12 months. The most common patient reported toxicities were fatigue $28(88 \%)$, diarrhea $17(53 \%)$ and hand/foot skin rash 14(43\%) [1].

\section{Discussion}

In November 2007 the Food and Drug Administration (FDA) approved sorafenib based on the results of the SHARP trial, an international randomized placebo controlled trial in patients with inoperable hepatocellular carcinoma. This was a groundbreaking advancement in the field of HCC. The SHARP trial [2] and Asia-Pacific trials [3] confirmed the efficacy of sorafenib in advanced HCC. In both of the trials patients in the treatment group received sorafenib $400 \mathrm{mg}$ twice daily. In the SHARP trial among the 297 patients that initially received one dose of sorafenib, 226 discontinued sorafenib. $38 \%$ discontinued the medication secondary to adverse events and $12 \%$ withdrew consent. The median duration of treatment was 5.3 months [2]. $80 \%$ of the patients in the sorafenib group had treatment related adverse events with $30 \%$ reported as grade 3 or higher. Despite using a lower starting dose, of sorafenib in our patients. The toxicities reported by the patient population on the SHARP Trial and the patient population we reviewed appeared to be different, with a higher percentage of specific toxicities reported by our patient population. Interestingly, fatigue and diarrhea (reported as $39 \%$ and $22 \%$ on the SHARP trial, were found to be much higher in our patient population $88 \%$ and $53 \%$. This seems to be a recurring theme noted among physicians in practice in the United States and may suggest a difference in the ability to tolerate higher doses of this medication in majority of the U.S. population as compared to European and Asian patients.

In an attempt to build on successes of the multi kinase inhibitor demonstrated in SHARP and Asia Pacific Trials, multiple phase III studies using a backbone of full-dose Sorafenib in combination with study agents compared to sorafenib at standard dose have been conducted. The chart provided below summarizes two of these 
major trials (Table 1).

Table 1: Major trials.

\begin{tabular}{|c|c|c|c|c|c|c|}
\hline $\begin{array}{c}\text { Studydrug } \\
\text { (Trial Acronym) }\end{array}$ & Trial Design & $\begin{array}{l}\text { Previous } \\
\text { Therapy }\end{array}$ & $\begin{array}{l}\text { Number } \\
\text { of Patients } \\
\text { Enrolled }\end{array}$ & $\begin{array}{l}\text { Primary } \\
\text { Endpoint }\end{array}$ & $\begin{array}{l}\text { Drug-Related } \\
\text { Discontinuation } \\
\text { Ratex }\end{array}$ & Conclusion \\
\hline $\begin{array}{l}\text { Sorafenib+doxorubicin } \\
\text { (CALGB-80802) [4] }\end{array}$ & $\begin{array}{l}\text { Sorafenib (400 mg } \\
\text { BID)+Doxorubicin (60mg/ } \\
\text { m2 q21 days) vsSorafenib }\end{array}$ & No & 346 & $\begin{array}{c}\text { OS } \\
(9.3 \text { vs } 10.5 \\
\text { mo })\end{array}$ & Not Reported & $\begin{array}{l}\mathrm{D}+\mathrm{S} \text { increased } \\
\text { toxicity without } \\
\text { improving OS }\end{array}$ \\
\hline $\begin{array}{c}\text { Sorafenib } \pm \text { erlotinib }(\text { SEARCH) } \\
{[5]}\end{array}$ & $\begin{array}{l}\text { Sorafenib+Erlotinib Vs. } \\
\text { Sorafenib alone }\end{array}$ & No & 731 & $\begin{array}{c}\text { OS } \\
(9.5 \text { vs } 8.5 \\
\text { mo })\end{array}$ & $45 \%$ vs $45 \%$ & $\begin{array}{l}\text { E+S increased } \\
\text { toxicity without } \\
\text { improving OS }\end{array}$ \\
\hline
\end{tabular}

Unfortunately, no such trial to date has resulted in statistically significant improvements in survival. Multiple mechanisms are likely responsible for this with one of these possibly due to unacceptable toxicities once dual agents at individual maximal tolerated doses are instituted $[4,5]$.

\section{Conclusion}

In this single institution retrospective study of outcomes following initiation of dose-reduced sorafenib at $200 \mathrm{mg}$ twice daily in advanced HCC. We postulate that this reduced dose approach did not seem to result in worse outcomes compared to historical controls possibly due to the ability to tolerate therapy for a longer duration of time. While one would be remiss in comparing apples to oranges, a prospective trial would be crucial to understanding the impact of reduced dose sorafenib on progression free survival and overall survival in advanced HCC patients. It would be interesting to prospectively compare a reduced dose of Sorafenib (200 mg twice daily) in combination with a promising agent to singleagent Sorafenib (400 mg twice daily) in an attempt to build on and improve progression-free survival and overall survival in this patient population

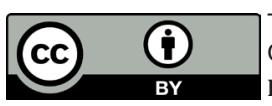

This work is licensed under Creative Commons Attribution 4.0 License

DOI: $10.19080 /$ ARGH.2017.03.555625

\section{References}

1. Olowokure O0, Singeltary B, Ghose A, Latif T, Shah S, et al. (2014) Sorafenib in hepatocellular carcinoma (HCC): is there a role for starting patients on a toltal daily dose of $400 \mathrm{mg}$ daily? J ClinOncol 32(Suppl 3): 364.

2. Llovet JM, Ricci S, Mazzaferro V, Hilgard P, Gane E, et al. (2008) Sorafenib in advanced hepatocellular carcinoma. N Engl J Med 359(4): 378-390.

3. Cheng AL, Kang YK, Chen Z, Tsao CJ, Qin S, et al. (2009) Efficacy and safety of sorafenib in patients in the Asia-Pacific region with advanced hepatocellular carcinoma: a phase III randomised, double-blind, placebo-controlled trial. Lancet Oncol 10(1): 25-34.

4. Abou-Alfa GK, Niedzwieski D, Knox JJ, Kaubisch A, Posey J (2016) Phase III randomized study of sorafenib plus doxorubicin versus sorafenib in patients with advanced hepatocellular carcinoma (HCC): CALGB 80802 (Alliance). J Clinoncol 34(Suppl 4S): 192.

5. Zhu AX, Rosmorduc O, Evans JTR, Ross PJ, Santoro A, et al. (2014) Search: a phase III, randomized, double-blind, placebo-controlled trial of sorafenib plus erlotinib in patients with advanced hepatocellular carcinoma. J ClinOncol 33(6): 559-566.

6. Zhu AX, Rosmorduc O, Evans JTR, Ross PJ, Santoro A, et al. SEARCH: APhase III, Randomized, Double-Blind, Placebo- Controlled Trial of Sorafenib PlusErlotinib in Patients With Advanced Hepatocellular Carcinoma J ClinOncol 33,2014. 559-566

\section{Your next submission with Juniper Publishers will reach you the below assets}

- Quality Editorial service

- Swift Peer Review

- Reprints availability

- E-prints Service

- Manuscript Podcast for convenient understanding

- Global attainment for your research

- Manuscript accessibility in different formats

( Pdf, E-pub, Full Text, Audio)

- Unceasing customer service

Track the below URL for one-step submission https://juniperpublishers.com/online-submission.php 